Article

\title{
Case Studies of Rock Bursts in Tectonic Areas with Facies Change
}

\author{
Weiyao Guo ${ }^{1,2} \mathbb{D}$, Qingheng $\mathrm{Gu}^{1,2, *}$, Yunliang Tan ${ }^{1,2, *}$ and Shanchao $\mathrm{Hu}{ }^{1,2, *}$ \\ 1 State Key Laboratory of Mining Disaster Prevention and Control Co-founded by Shandong Province and the \\ Ministry of Science and Technology, Shandong University of Science and Technology, Qingdao 266590, \\ China; gwy2018@sdust.edu.cn \\ 2 School of Mining and Safety Engineering, Shandong University of Science and Technology, Qingdao 266590, \\ China \\ * Correspondence: skd995571@sdust.edu.cn (Q.G.); skd991730@sdust.edu.cn (Y.T.); \\ human86@sdust.edu.cn (S.H.); Tel.: +86-15610451523 (Q.G.); +86-13583277017 (Y.T.); +86-15063992579 (S.H.)
}

Received: 20 February 2019; Accepted: 3 April 2019; Published: 8 April 2019

\begin{abstract}
Although tectonic areas with facies change (i.e., variation of coal seam thickness, coal seam dip angle, or coal quality) are one of the three major geological structures that induce rock bursts, case studies of rock bursts in these tectonic structures are rare. The main objective of this study is to illustrate this issue and provide case studies that may inspire future research. Based on several typical cases of rock bursts induced by tectonic areas with facies change, the conditions conducive for these bursts are introduced and investigated in detail. Subsequently, numerical simulation is performed, showing that stress concentration exists in regions with variable coal seam thicknesses or dip angle. When stoping or tunnelling approaches this region, the peak stress increases rapidly. Thus, the burst occurs via a mechanism involving the superposition of high in-situ stress from tectonic areas with facies change and abutment pressure from stoping or tunnelling, leading to high stress concentration. Strategies for mitigating rock bursts are also provided. Rock bursts induced by tectonic areas with facies change can be mitigated by avoiding regions of high tectonic stress concentration and reducing mining induced stress.
\end{abstract}

Keywords: geology; rock burst; tectonic area; mechanism; case histories

\section{Introduction}

Rock burst are common dynamic disasters that occur during underground mining [1-7]. Although scholars have focused on this issue for several decades, the mechanisms of rock bursts remain inadequately understood. It is generally acknowledged that geological structures including folds, faults, and tectonic areas with facies change contribute to the occurrence of rock burst hazards and other dynamic disasters [8-12]. According to incomplete statistics, rock bursts induced by geological structures account for nearly $70 \%$ of the total rock burst occurrences in China [13]. Extensive studies have been performed regarding the occurrence of rock bursts induced by geological structures. For fault induced rock bursts, Jiang et al. [14] and Li et al. [15] used FLAC3D numerical software to study the fault activation, and Dou et al. [16] investigated fault-slip rock bursts comprehensively via theoretical analysis, laboratory tests, numerical simulation, and engineering practice. Sainoki and Mitri [17] studied the dynamic behaviour of fault slips influenced by mining activities, and $\mathrm{Hu}$ et al. [18] developed a mechanical model of fault slipping. For fold-induced rock bursts, Wang et al. [19] and Chen et al. [20] studied the stress distribution in the core of the fold using numerical simulation.

Mining in tectonic areas with facies change (Figure 1) can easily cause dynamic disasters. However, limited literature is available regarding the underlying mechanisms. For example, Sun et al. [21] 
studied 14 rock bursts related to the variation of coal seam thickness, and Zhai et al. [22] found that the variation of coal seam thickness was significantly correlated to coal and gas outbursts, and concluded that when the coal seam thickness suddenly increases, the gas content and the associated pressure continually increase. Case studies on the matter are important and valuable, but only a few recorded histories and experiences of rock bursts caused by tectonic areas with facies change have been reported. The literature on related mechanisms is rare except for a few studies on the variation of coal seam thickness. For example, Zhao et al. [23] studied mechanism of rock bursts induced by the variation of coal seam thickness, showing that stoping from thin to thick coal seams was beneficial for controlling rock bursts. In general, research attention for these kinds of rock bursts remains insufficient.

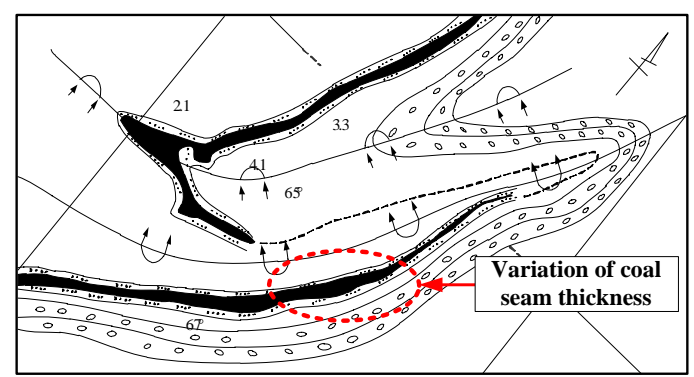

(a)

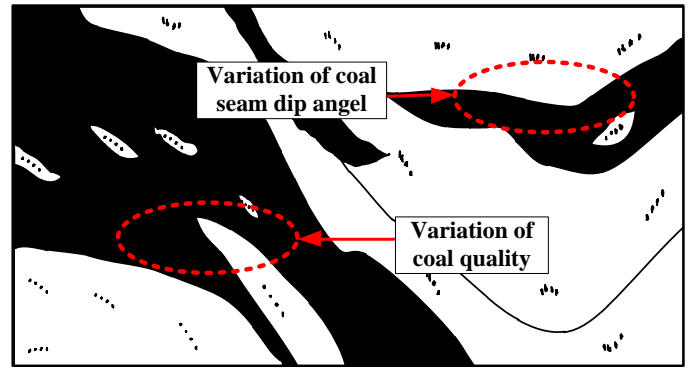

(b)

Figure 1. Tectonic areas with facies change. (a) Variation of coal seam thickness, (b) variations of coal seam dip angle and coal quality [13].

Therefore, to provide some references for studying the burst mechanism induced by tectonic areas with facies change, case studies of rock bursts related to the aforementioned geological structures are analyzed first. The occurrence conditions are introduced and investigated in detail. Subsequently, the occurrence mechanism of these rock bursts is discussed using FLAC3D simulation. Finally, suggestions for mitigating rock bursts induced by tectonic areas with facies change are provided for reference in further studies regarding burst mitigation.

\section{Case Histories of Rock Bursts Related to the Variation of Coal Seam Thickness}

\subsection{Rock Burst in Mine A}

A region with variation in the coal seam thickness was present in the central area of the headgate of W-No.1 mining face in Mine A, which was approximately $700 \mathrm{~m}$ deep. The variation of the coal seam thickness was $1.8-3.5 \mathrm{~m}$ with an average value of $2.9 \mathrm{~m}$. The variation of the dip angle was $11-14^{\circ}$ with an average dip angle of $12^{\circ}$. The floor, the immediate roof, and the main roof were composed of sandstone and fine siltstone with an average thickness of 4, 3, and $20 \mathrm{~m}$, respectively. The minimum, the median, and the maximum principal stresses were 9.8, 19.6, and $23.1 \mathrm{MPa}$, respectively. The region of interest was in the plane of $\sigma_{1}$ and $\sigma_{3}$ [13]. On 28 June 2009, when the longwall face was $140 \mathrm{~m}$ away from the uphill roadway, a rock burst occurred at the headgate. This burst caused damage to the headgate $17 \mathrm{~m}$ in length with rib spalling $0.8-1.2 \mathrm{~m}$ thick. Additionally, the burst influenced the longwall face, which was $33 \mathrm{~m}$ in length. The burst site and damage photos are shown in Figure 2. 


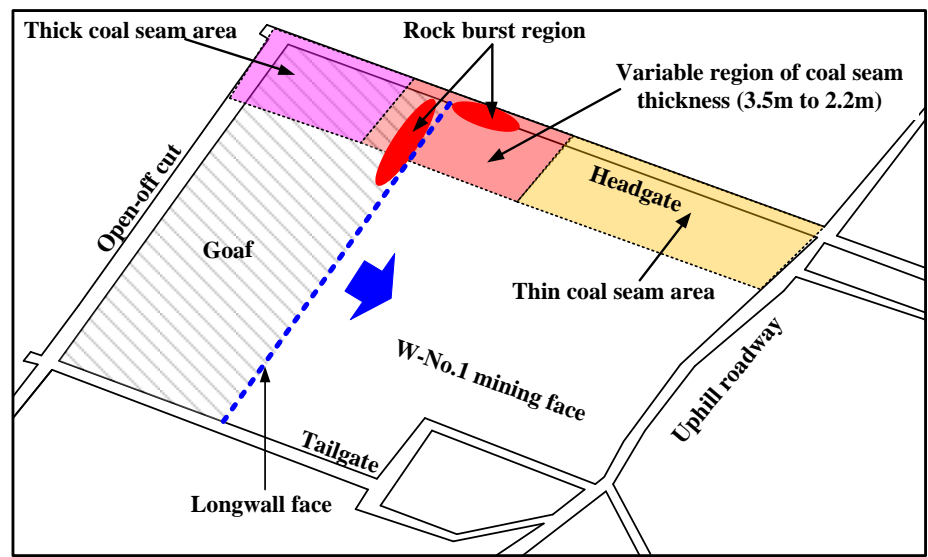

(a)

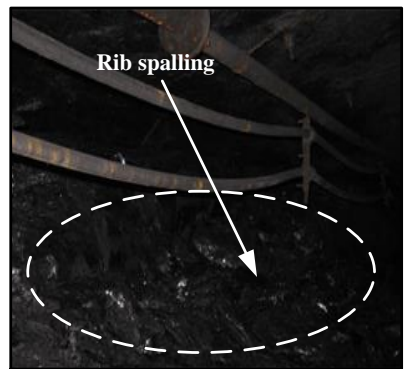

(b)

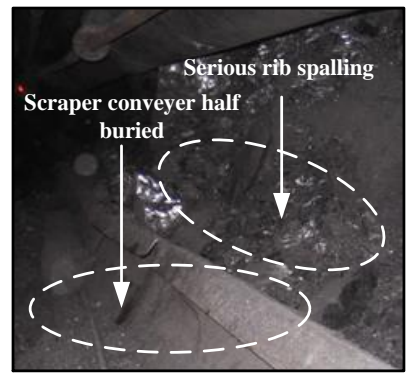

(c)

Figure 2. Rock burst region in the W-No. 1 mining face and photos of the rock burst damage, (a) rock burst region, (b) roadway damage, (c) longwall face damage.

As shown in Figure 2a, this event occurred in the region where the coal seam thickness varied from 3.5 to $2.2 \mathrm{~m}$. The region with variable coal seam thickness was a tectonic area with facies change. Related reports suggested that tectonic areas with facies changes also exhibit high in-situ stress concentrations, except in cases of faults and folds $[3,13]$. When the longwall face advanced towards this region, the critical stress was easily achieved under the influence of abutment pressure, tectonic stress, self-weight, and mining disturbances, resulting in a rock burst. It should be noted that no mitigation methods were implemented before the occurrence of this rock burst.

\subsection{Rock Burst in Mine B}

The buried depth of the No. 1305 mining face in Mine B, a typical mining face in the region with variable of coal seam thickness, was approximately $980 \mathrm{~m}$. The variation in the coal seam thickness was $2.1-8.6 \mathrm{~m}$ with an average value of $6.02 \mathrm{~m}$. The variation in the dip angle was $0-11^{\circ}$ with an average dip angle of $3^{\circ}$. The floor, the immediate roof, and the main roof were composed of mudstone, siltstone, and medium sandstone, with average thicknesses of 1.7, 2.8, and $8.3 \mathrm{~m}$, respectively. An intense rock burst occurred at the No. 1305 mining face when beginning to stope on 29 July 2015, as illustrated in Figure 3a. The rock burst damaged the entire longwall face, $60 \mathrm{~m}$ long tailgate, and the $40 \mathrm{~m}$ long headgate, including floor heave, roof fall, support bending, and coal cutter damage, as shown in Figure 3b,c.

A region with obviously variable coal seam thickness passes through this rock burst region. The rock burst region at the No. 1305 mining face was already in a high stress state due to its deep burial depth. The open-off cut of No. 1305 mining face was selected in a region with variable coal seam thickness, primarily due to a lack of awareness regarding rock bursts induced by variable coal seam thickness. When stoping began, the stress soon reached a critical value because of the additional abutment pressure and tectonic stress, resulting in the rock burst. In practice, the open-off cut should be located in a general area without high tectonic stress to prevent such disasters. 


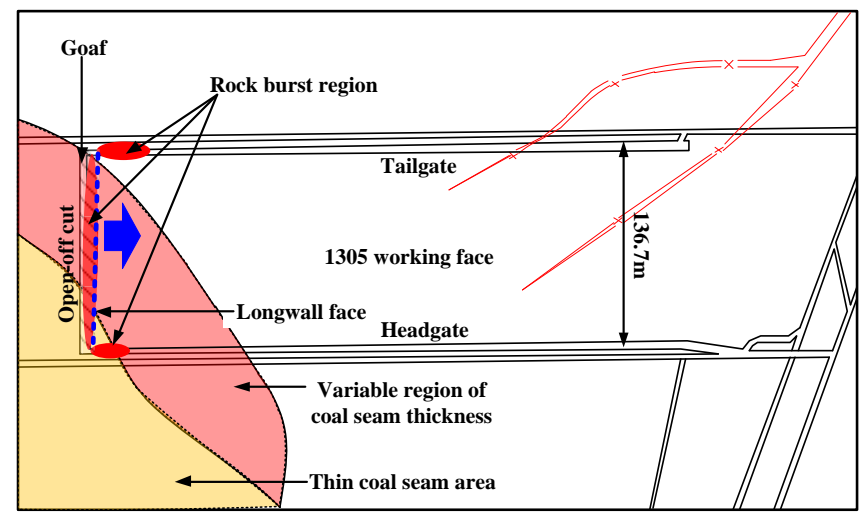

(a)

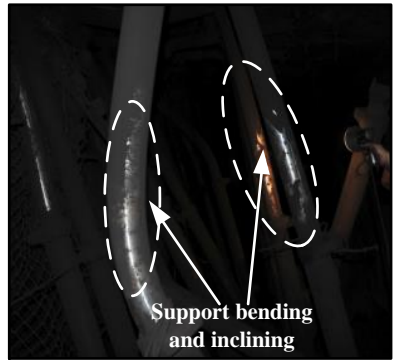

(b)

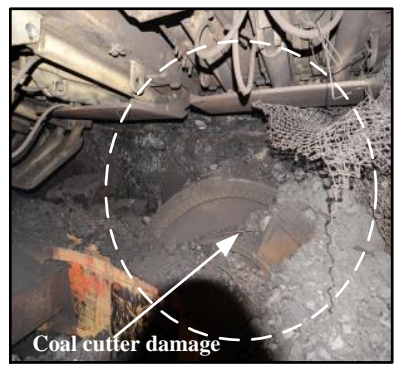

(c)

Figure 3. Rock burst region in the No. 1305 mining face and photos of the rock burst damage, (a) rock burst region, (b) roadway damage, (c) longwall face damage.

\subsection{Rock Burst in Mine C}

On 18 May 2013, a rock burst occurred in the downhill roadway on the east LW2302S mining face in Mine C, as illustrated in Figure 4. The buried depth was $>900 \mathrm{~m}$, and above the mining face was a $600 \mathrm{~m}$ thick alluvium stratum. This rock burst destroyed a $150 \mathrm{~m}$ long roadway, including server floor heaves and roof falls. A facies change belt, which assisted in the formation of variable coal seam thickness, crossed the rock burst region, indicating that the area was in a state of high tectonic stress. The roadway was also influenced by the abutment pressure on the LW2302S mining face [24], achieving the critical stress required for the rock burst in the red zone. However, this event could have been mitigated or prevented if appropriate measures were taken in the region with variable coal seam thickness before stoping.

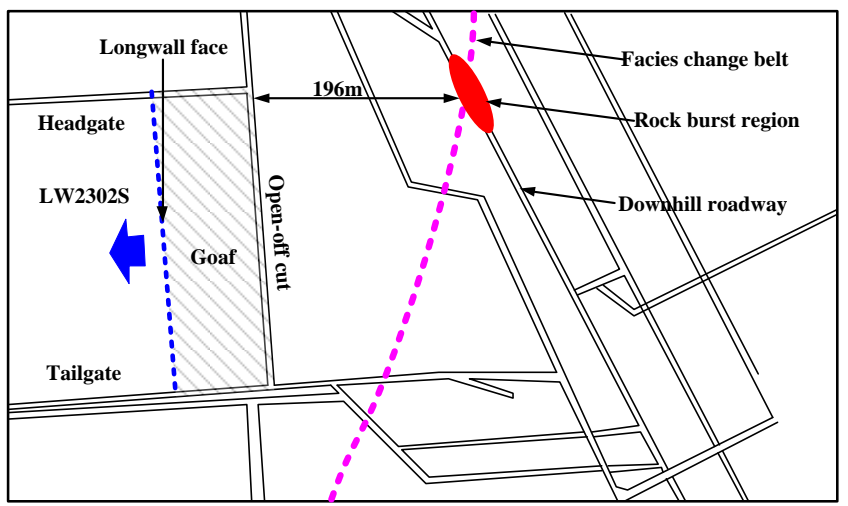

Figure 4. Rock burst region in the LW2302S mining face [24]. 


\section{Case Histories of Rock Bursts Related to the Variation of Coal Seam Dip Angle}

\subsection{Rock Burst in Mine D}

On 5 August 2013, an intense rock burst occurred behind the $200 \mathrm{~m}$ long heading face in the No. 3302 mining face while tunnelling the tailgate in Mine D, as shown in Figure 5a [25]. This rock burst destroyed the nearly $150 \mathrm{~m}$ long roadway. Figure $5 \mathrm{~b}, \mathrm{c}$ shows images of the related burst damage. This was the first mining face and was buried $1260 \mathrm{~m}$ deep. The average coal seam thickness and dip angle were approximately $9 \mathrm{~m}$ and $8^{\circ}$, respectively. The roof was composed of 5-20 m thick sandstone. Figure 5a shows that the rock burst occurred in the region with variable coal seam dip angles. In other words, the observations indicated that the variable coal seam dip angle likely contributed to this rock burst.

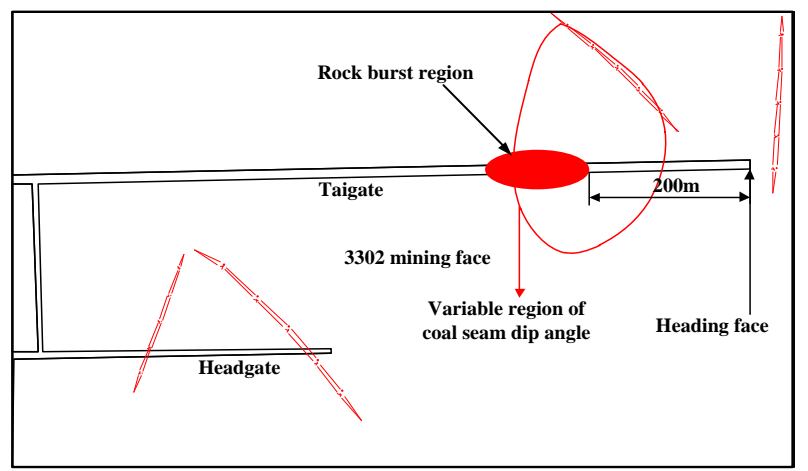

(a)
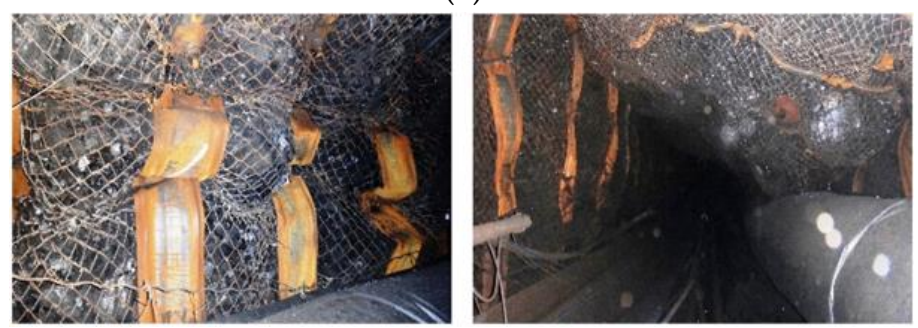

(b)

Figure 5. Rock burst region in the No. 3302 mining face and photos of the associated rock burst damage [25], (a) rock burst region, (b) roadway damage

\subsection{Rock Burst in Mine E}

The buried depth of the No. 2 mining face in Mine E was $>1000 \mathrm{~m}$. The coal seam thickness varied from 0.3 to $2.7 \mathrm{~m}$ with an average thickness of $1.5 \mathrm{~m}$. The dip angle varied from 12 to $29^{\circ}$ with an average dip angle of $18^{\circ}$. The floor, the immediate roof, and the main roof were composed of siltstone and fine sandstone, whose corresponding thicknesses were 10-17, 11-13, and 17-33 m, respectively. The test results of in-situ stress in Mine E are listed in Table 1. The results showed that the stress state was in the plane of $\sigma_{1}$ and $\sigma_{3}$, and that horizontal stress was the dominant stress mode.

Table 1. Test results of the in-situ stress in Mine E [26].

\begin{tabular}{|c|c|c|c|c|c|c|c|c|c|}
\hline \multirow[b]{2}{*}{ Depth/m } & \multicolumn{3}{|c|}{ Maximum Principal Stress $\left(\sigma_{1}\right)$} & \multicolumn{3}{|c|}{ Median Principal Stress $\left(\sigma_{2}\right)$} & \multicolumn{3}{|c|}{ Minimum Principal Stress $\left(\sigma_{3}\right)$} \\
\hline & Value/MPa & $\begin{array}{l}\text { Azimuth } \\
\text { Angle/ }{ }^{\circ}\end{array}$ & $\begin{array}{c}\text { Dip } \\
\text { Angle } /^{\circ}\end{array}$ & Value/MPa & $\begin{array}{l}\text { Azimuth } \\
\text { Angle/ } /^{\circ}\end{array}$ & $\begin{array}{c}\text { Dip } \\
\text { Angle/ } /^{\circ}\end{array}$ & Value/MPa & $\begin{array}{c}\text { Azimuth } \\
\text { Angle }{ }^{\circ}\end{array}$ & $\begin{array}{c}\text { Dip } \\
\text { Angle } /^{\circ}\end{array}$ \\
\hline 510 & 20.50 & 252.00 & -7.00 & 12.20 & -16.00 & -5.00 & 9.30 & 109.00 & -80.00 \\
\hline 465 & 19.10 & 232.00 & 12.00 & 12.40 & -2.00 & 70.00 & 8.10 & 139.00 & 15.00 \\
\hline 580 & 22.60 & 213.00 & 1.00 & 12.60 & -58.00 & -80.00 & 9.20 & 122.00 & -9.00 \\
\hline
\end{tabular}


On 25 October 2016, a rock burst occurred at the junction between the open-off cut and tailgate under the influence of a blasting disturbance, as shown in Figure 6. This rock burst caused rib spalling of $0.1-0.3 \mathrm{~m}$ in width and failure of a few cables. When this event occurred, no mining activities were being performed, while the dip angle of coal seam varied from 18 to $37^{\circ}$ in this region. Thus, it could be concluded that the variable dip angle most significantly contributed to this burst.

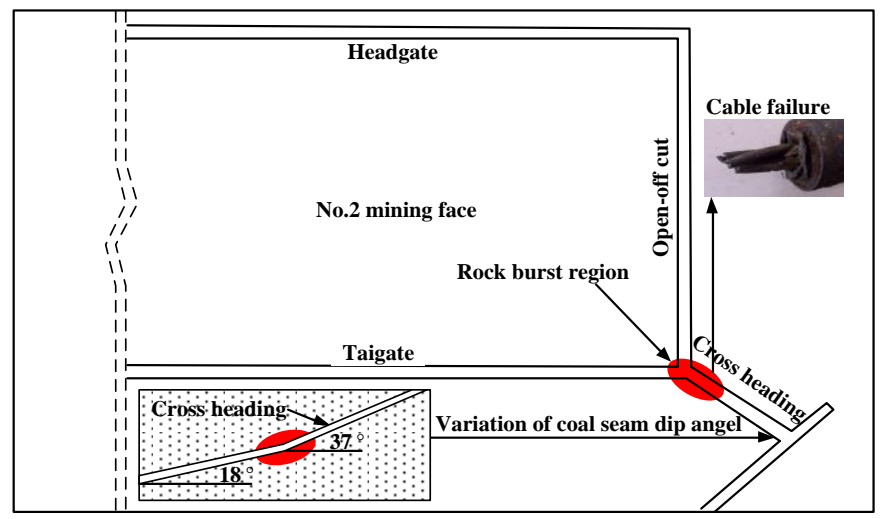

Figure 6. Rock burst region in the No. 2 mining face.

\section{Case Histories of Rock Bursts Related to the Variation of Coal Quality}

\subsection{Rock Burst in Mine E}

The buried depth of the No. 1 mining face in Mine E was $>800 \mathrm{~m}$. The variation of coal seam thickness was $0.6-2.2 \mathrm{~m}$ with an average value of $1.5 \mathrm{~m}$. The variation of dip angle was $10-30^{\circ}$ with an average dip angle of $16^{\circ}$. The floor, the immediate roof, and the main roof were composed of siltstone and fine sandstone with thicknesses of 10-17, 11-13, and 17-33 m, respectively. On 10 August 2016, a rock burst occurred in the uphill roadway near the No. 1 mining face during tunnelling, as shown in Figure 7. This rock burst caused a floor heave of $0.2-0.5 \mathrm{~m}$ in height and shifting of the transportation track.

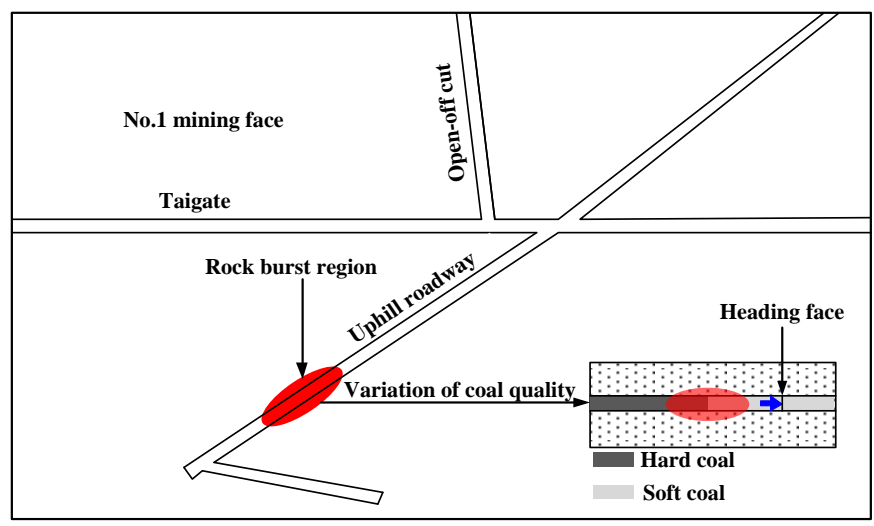

Figure 7. Rock burst region in the No. 1 mining face.

The burst occurred in a region where the coal hardness changed, as shown in Figure 7. Because of the lack of knowledge of rock bursts induced by variation in coal quality, no mitigation methods were considered before tunnelling. When tunnelling in this region, the stress reached a critical value and caused the rock burst. This event could have been avoided if proper mitigation was implemented. 


\subsection{Rock Burst in Mine F}

On 28 August 2011, a rock burst occurred behind the heading face 5-6 $\mathrm{m}$ in length in the No. 2302 mining face during tailgate tunnelling in Mine F, as illustrated in Figure 8. The variation of the coal seam thickness was $3.8-8.5 \mathrm{~m}$ with an average value of $7.7 \mathrm{~m}$. The variation of the dip angle was 6.0-9.6 with an average value of $7.8^{\circ}$. This rock burst caused a few pieces of coal to be ejected, and the burst region was buried at a depth of $900 \mathrm{~m}$. Figure 8 clearly shows that the distance between the burst region and fault was approximately $222 \mathrm{~m}$, indicating that the region was not influenced by the fault. The field investigation showed that the coal on the left side of the heading face was harder than that on the right side. Fortunately, when mitigation methods were implemented on the left side, no further rock bursts occurred [27]. Therefore, it could be concluded that this rock burst was induced by variation in the coal quality.

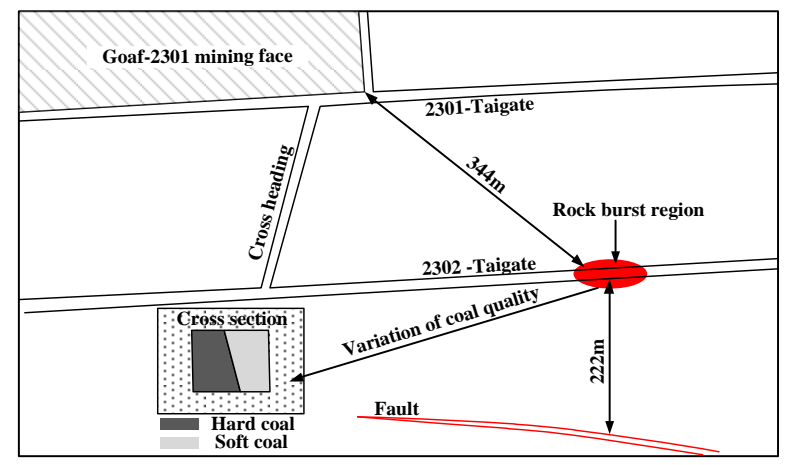

Figure 8. Rock burst region in the No. 1 mining face [26].

\section{Discussions}

From the representative rock burst case studies in tectonic areas with facies change provided above, it can be concluded that when tunnelling or stoping approaches tectonic areas with facies changes, the critical stress required for rock bursts can easily be achieved. Therefore, tectonic areas with facies change require screening for both faults and folds. In this section, we discuss the mechanisms of rock bursts induced by tectonic areas with facies change and related mitigation suggestions.

\subsection{Rock Burst Mechanism Induced by Tectonic Areas with Facies Change}

Zhao et al. [23] showed that in-situ stress concentration and stress gradient zones are present in regions with variable coal seam thickness, as shown in Figure 9. In-situ stress in the thinning area was observed to be larger than that in the thickening area. The authors also found that larger variation amplitudes resulted in larger stress gradients. For example, when the coal seam thickness varied between 5 and $2 \mathrm{~m}$, the value of variation amplitude was $6.3 \mathrm{MPa}$, while it was only $1.6 \mathrm{MPa}$ when the coal seam thickness varied from 5 to $4 \mathrm{~m}$.

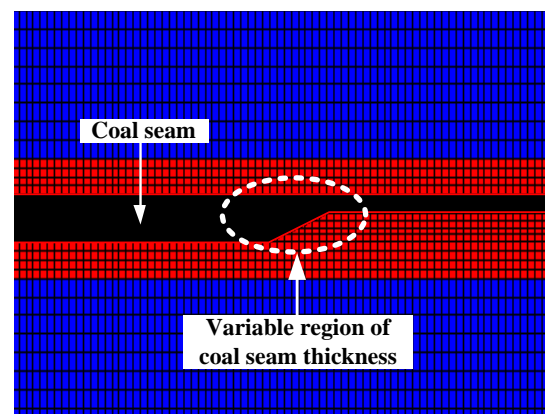

(a)

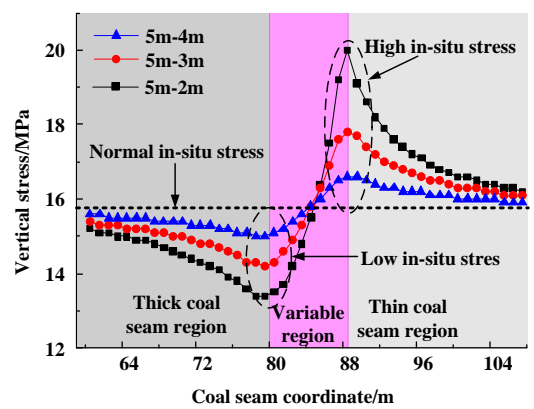

(b)

Figure 9. Cont. 


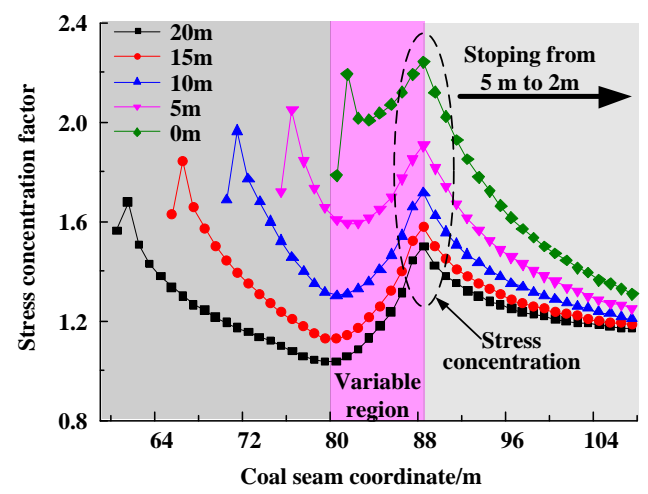

(c)

Figure 9. Numerical model of the variation of coal seam thickness, in-situ stress distribution, and abutment pressure distribution [23], (a) numerical model of the variation of coal seam thickness, (b) distribution of the in-situ stress, (c) distribution of abutment pressure when stoping with coal seam thickness of 5 to $2 \mathrm{~m}$.

To further analyze the abutment pressure distribution during the stoping process in the variable coal seam thickness region, the abutment pressure distribution at different distances between the variable region (5-2 $\mathrm{m}$ ) and longwall face is shown in Figure 9c. The stress concentration factor in the variable region showed an increasing trend with decreasing distance between the longwall face and the variable region. When the distance decreased from 20 to $5 \mathrm{~m}$, the stress concentration factor in the variable region gradually increased from 1.39 to 1.89 . If the peak abutment pressure stress approaches this region, stress superposition can easily occur, enhancing the risk of rock bursts.

Considering that the dip angles of the coal seam varied from $0^{\circ}$ to $15-45^{\circ}$, seven numerical variation models of dip angles were established to study the in-situ stress distribution in this region, as shown in Figure 10a. The displacement boundary conditions, the constitutive model, and the mechanical properties of the coal, rock, etc. used in this simulation were similar to the available literature [23], except for the numerical model. The obtained in-situ stress distribution is shown in Figure 10b. From Figure 10b, it is clear that there was a stress concentration zone in the region with variable coal seam dip angles, and the stress concentration increased as the variable range of the dip angle increased.

Figure 10c shows the abutment pressure distribution at different distances between the variable region $\left(0-30^{\circ}\right)$ and the longwall face. The stress concentration factor in the variable region of the dip angle also showed an increasing trend with decreasing distance between the longwall face and the variable region. When the distance decreased from 20 to $5 \mathrm{~m}$, the stress concentration factor in the variable region rapidly increased from 1.23 to 1.98 . This indicated that when the longwall face approached the variable dip angle region, superposition of the abutment pressure and tectonic stress could easily occur, potentially inducing a rock burst.

For regions with variable coal quality, scholars have reached a consensus that under similar geological conditions, the in-situ stress of a hard coal seam is larger than that of a soft coal seam $[27,28]$. Similar stress concentration zones in regions with variable coal seam thicknesses and dip angles were also observed.

Based on the analysis of the in-situ stress distribution, a schematic of the rock burst mechanisms was generated and is shown in Figure 11. The mechanisms of rock bursts induced by tectonic areas with facies changes can be described as follows-in-situ stress concentration zones exist in critical areas (Figure 11a). When stoping or tunnelling approaches the in-situ stress concentration zones, these areas will experience high stress caused by the superposition of the high in-situ stress concentration from tectonic areas with facies changes and abutment pressure from stoping or tunnelling (Figure 11b), leading to rock bursts. 


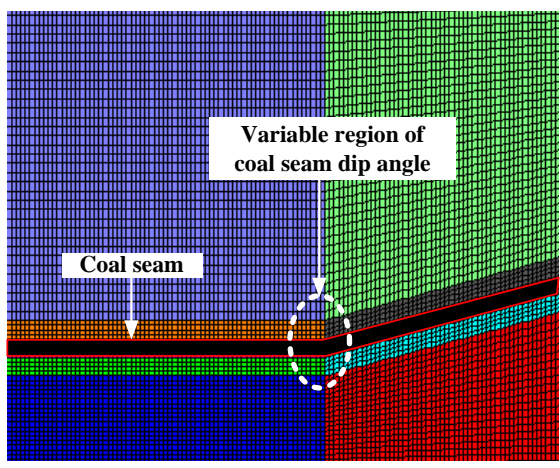

(a)

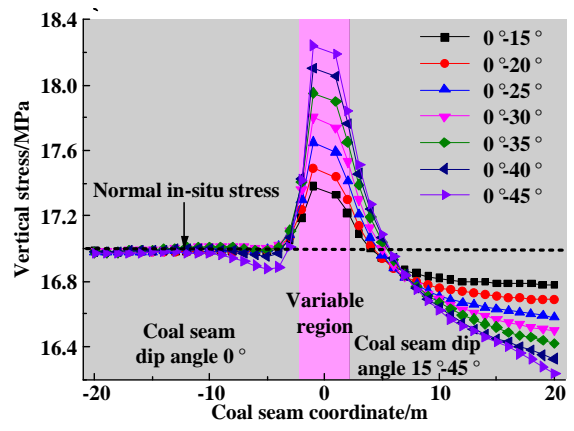

(b)

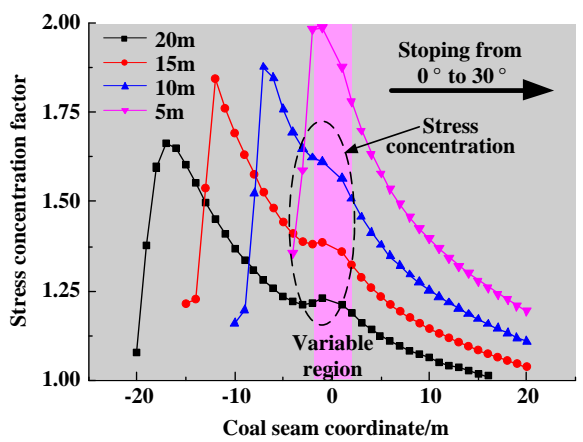

(c)

Figure 10. Numerical model of the variation of coal seam dip angle, in-situ stress distribution, and abutment pressure distribution, (a) numerical model of the variation of coal seam dip angle, (b) in-situ stress distribution, (c) distribution of abutment pressure when stoping from a dip angle of 0 to $30^{\circ}$.

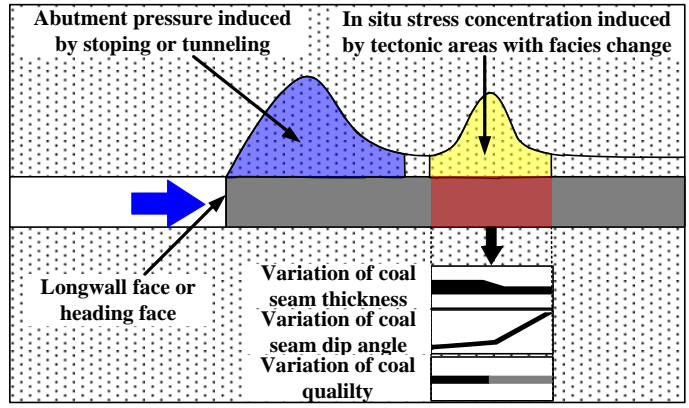

(a)

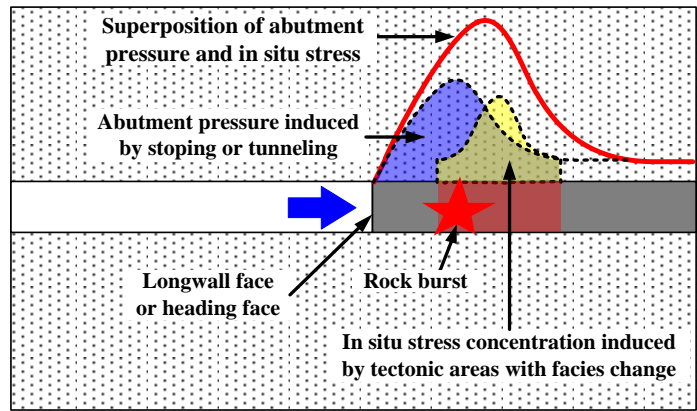

(b)

Figure 11. Schematic of the rock burst mechanisms induced by tectonic areas with facies changes, (a) before superposition of the abutment pressure and in-situ stress, (b) superposition of the abutment pressure and in-situ stress.

\subsection{Suggestions for Mitigating Rock Bursts Induced by Tectonic Areas with Facies Change}

Based on the case studies and determination of rock burst mechanisms, it is clear that rock bursts induced by tectonic areas with facies change can be mitigated by avoiding regions with high tectonic stress concentration and reducing mining-induced stress. Three basic suggestions for mitigating such rock bursts are proposed herein. First, when stoping or tunnelling, the roadway layout should avoid high tectonic stress concentration areas. Second, if tectonic areas with facies changes cannot be avoided while stoping or tunnelling, mitigation methods should be implemented more intensely than for areas not influenced by tectonic stress. Third, peak stress concentration areas should be thoroughly transferred into deep coal walls. 


\section{Conclusions}

In this study, several cases of rock bursts related to tectonic areas with facies changes were analyzed in detail. Subsequently, the underlying mechanisms of these rock bursts as well as some mitigation strategies were discussed. The main conclusions are as follows:

(1) The rock burst case studies showed that tectonic areas with facies changes, including variations in coal seam thickness, coal seam dip angle, and coal quality, play an important role in tectonic rock bursts. Special attention should be paid to such rock bursts compared to those induced by the more widely studied faults and folds.

(2) Numerical simulation was used to investigate existing stress concentration in regions with variable coal seam thickness or dip angle. The stress concentration increases gradually as the variable range of coal seam thickness or dip angle increases. When stoping or tunnelling in these regions, the peak stress will increase rapidly.

(3) The superposition of high in-situ stress from tectonic areas with facies changes and abutment pressure from stoping or tunnelling leads to high stress concentration. Three main suggestions were provided for mitigating rock bursts induced by tectonic areas with facies changes. First, the roadway layout should avoid high tectonic stress concentration areas. Second, if stoping or tunnelling cannot avoid these sensitive areas, mitigation methods must be implemented. Third, peak stress concentration areas should be thoroughly transferred into deep coal walls.

Overall, this study aimed to highlight the issue of rock bursts induced by tectonic areas with facies changes for researchers interested in underground engineering and to provide case studies to inspire further research in this field.

Author Contributions: All the authors contributed to this paper. Q.G. prepared and edited the manuscript. W.G. provided methodological guidance in the research process. S.H. partially participated in the literature search. Y.T. and W.G. participated in revising the manuscript.

Funding: This research was funded by National Key R\&D Program of China (No. 2018YFC0604703), National Natural Science Foundation of China (Nos. 51874190), Major Program of Shandong Province Natural Science Foundation (No. ZR2018ZA0603), Shandong Province Natural Science Foundation (No. ZR2017BEE013), Scientific Research Foundation of Shandong University of Science and Technology for Recruited Talents (No. 2017RCJJ009), Taishan Scholar Engineering Construction Fund of Shandong Province of China (ts201511026) and Taishan Scholar Talent Team Support Plan for Advantaged \& Unique Discipline Areas.

Acknowledgments: We are grateful to Shandong University of Science and Technology for providing us with the scientific research platform and all the reviewers for their specific comments and suggestions.

Conflicts of Interest: The authors declare no conflict of interest.

\section{References}

1. Tan, Y.L.; Yu, F.H.; Ning, J.G.; Zhao, T.B. Design and construction of entry retaining wall along a gob side under hard roof stratum. Int. J. Rock Mech. Min. Sci. 2015, 77, 115-121. [CrossRef]

2. Zhao, H.C.; Kaunda, R.B. Numerical Assessment of the Influences of Gas Pressure on Coal Burst Liability. Energies 2018, 11, 260. [CrossRef]

3. Zhao, T.B.; Guo, W.Y.; Tan, Y.L.; Yin, Y.C.; Cai, L.S.; Pan, J.F. Case studies of rock bursts under complicated geological conditions during multi-seam mining at a depth of $800 \mathrm{~m}$. Rock Mech. Rock Eng. 2018, 51, 1539-1564. [CrossRef]

4. Yin, Y.C.; Zhao, T.B.; Zhang, Y.B.; Tan, Y.L.; Qiu, Y.; Taheri, A.; Jing, Y. An Innovative Method for Placement of Gangue Backfilling Material in Steep Underground Coal Mines. Minerals 2019, 9, 107. [CrossRef]

5. Khademian, Z.; Ugur, O. Computational framework for simulating rock burst in shear and compression. Int. J. Rock Mech. Min. 2018, 110, 279-290. [CrossRef]

6. Guo, W.Y.; Tan, Y.L.; Yu, F.H.; Zhao, T.B.; Hu, S.C.; Huang, D.M.; Qin, Z. Mechanical behavior of rock-coal-rock specimens with different coal thickness. Geomech. Eng. 2018, 5, 1017-1027.

7. Li, N.; Jimenez, R. A logistic regression classifier for long-term probabilistic prediction of rock burst hazard. Nat. Hazards 2018, 90, 197-215. [CrossRef] 
8. Vižintin, G.; Kocjančič, M.; Vulić, M. Study of Coal Burst Source Locations in the Velenje Colliery. Energies 2016, 9, 507. [CrossRef]

9. Wang, J.; Ning, J.G.; Jiang, J.Q.; Bu, T.T. Structural characteristics of strata overlying of a fully mechanized longwall face: A case study. J. S. Afr. Inst. Min. Metall. 2018, 118, 1195-1204. [CrossRef]

10. Jiang, Y.D.; Pan, Y.S.; Jiang, F.X.; Dou, L.M.; Ju, Y. State of the art review on mechanism and prevention of coal bumps in China. J. China Coal Soc. 2014, 39, 205-213.

11. Xiao, Y.X.; Feng, X.T.; Li, S.J.; Feng, G.L.; Yu, Y. Rock mass failure mechanisms during the evolution process of rockbursts in tunnels. Int. J. Rock Mech. Min. Sci. 2016, 83, 174-181. [CrossRef]

12. Liu, X.S.; Tan, Y.L.; Ning, J.G.; Lu, Y.W.; Gu, Q.H. Mechanical properties and damage constitutive model of coal in coal-rock combined body. Int. J. Rock Mech. Min. Sci. 2018, 110, 140-150. [CrossRef]

13. Guo, W.Y.; Zhao, T.B.; Tan, Y.L.; Yu, F.H.; Hu, S.C.; Yang, F.Q. Progressive mitigation method of rock bursts under complicated geological conditions. Int. J. Rock Mech. Min. Sci. 2017, 96, 11-22. [CrossRef]

14. Jiang, Y.D.; Wang, T.; Zhao, Y.X.; Wang, C. Numerical simulation of fault activation pattern induced by coal extraction. J. China Univ. Min. Technol. 2013, 42, 1-5.

15. Li, Z.H.; Dou, L.M.; Cao, A.Y.; Fan, J.; Mu, Z.L. Mechanism of fault slip induced rockburst during mining. J. China Coal Soc. 2011, 36, 69-73.

16. Dou, L.M.; Mu, Z.L.; Li, Z.L.; Cao, A.Y.; Gong, S.Y. Research progress of monitoring, forecasting, and prevention of rockburst in underground coal mining in China. Int. J. Coal Sci. Technol. 2014, 1, $278-288$. [CrossRef]

17. Sainoki, A.; Mitri, H.S. Dynamic behaviour of mining-induced fault slip. Int. J. Rock Mech. Min. Sci. 2014, 66, 19-29. [CrossRef]

18. Hu, S.C.; Tan, Y.L.; Ning, J.G.; Guo, W.Y.; Liu, X.S. Multi-parameter monitoring and prevention of fault-slip rock burst. Shock Vib. 2017, 2017, 7580109.

19. Wang, S.B.; Zhang, X. Relation between geological structures and in-situ stresses in underground coalmines. J. China Coal Soc. 2008, 33, 738-742.

20. Chen, G.X.; Dou, L.M.; Qiao, Z.D.; Lu, C.P.; Gong, S.Y. The stress field distribution in folding structure areas and its impaction on rock burst. J. China Univ. Min. Technol. 2008, 37, 751-755.

21. Sun, Z.W. Numerical Simulation on Stress Field distribution in partial transformation area of coal seam. Ground Press. Strata Control 2003, 20, 95-100.

22. Zhai, C.; Xiang, X.W.; Xu, J.Z.; Wu, S.L. The characteristics and main influencing factors affecting coal and gas outbursts in Chinese Pingdingshan mining region. Nat. Hazards 2016, 82, 507-530. [CrossRef]

23. Zhao, T.B.; Guo, W.Y.; Tan, Y.L.; Zhang, Z.; Cheng, K.K. Mechanics mechanism of rock burst caused by mining in the variable region of coal thickness. J. China Coal Soc. 2016, 41, 1659-1666.

24. Zhu, S.T.; Feng, Y.; Jiang, F.X. Determination of abutment pressure in coal mines with extremely thick Alluvium stratum: A typical kind of rockburst mines in China. Rock Mech. Rock Eng. 2016, 49, 1943-1952. [CrossRef]

25. Jiang, F.X.; Feng, Y.; Kouame, K.J.A.; Wang, J.C. Mechanism of creep-induced rock burst in extra-thick coal seam under high ground stress. Chin. J. Geotech. Eng. 2016, 37, 1762-1768.

26. Han, J.; Zhang, H.W.; Lan, T.W.; Li, S. Geodynamic environment of rockburst in western Beijing coalfield. J. China Coal Soc. 2014, 39, 1056-1062.

27. Jiang, L.S.; Wu, Q.S.; Wu, Q.L.; Wang, P. Fracture failure analysis of hard and thick key layer and its dynamic response characteristics. Eng. Fail. Anal. 2019, 98, 118-130. [CrossRef]

28. Wang, C.W.; Jiang, F.X.; Liu, J.H. Analysis on control action of geologic structure on rock burst and typical cases. J. China Coal Soc. 2012, 37, 263-268.

(C) 2019 by the authors. Licensee MDPI, Basel, Switzerland. This article is an open access article distributed under the terms and conditions of the Creative Commons Attribution (CC BY) license (http:/ / creativecommons.org/licenses/by/4.0/). 